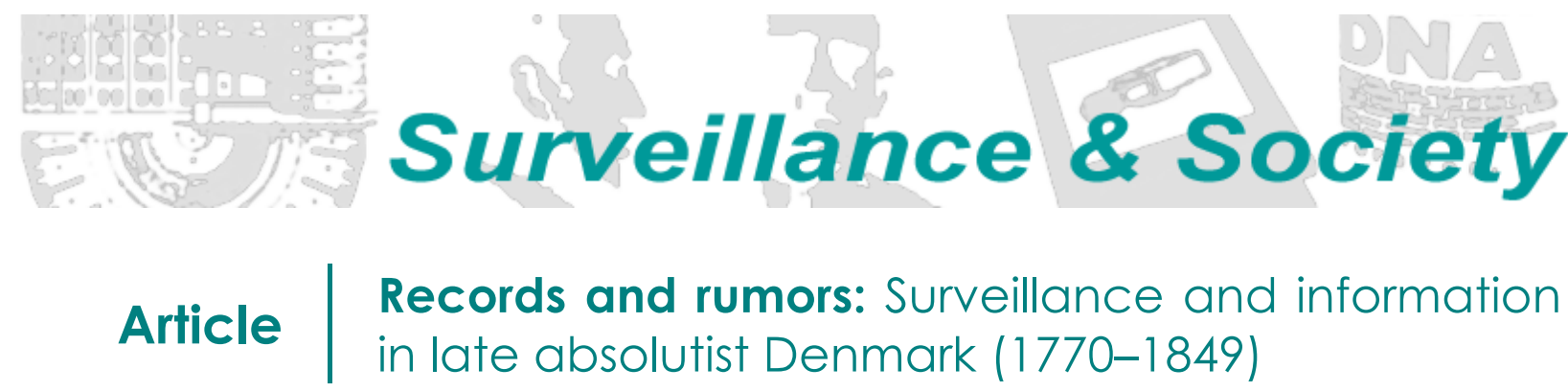

\title{
Laura Skouvig
}

København Universitet, Denmark.

laura.skouvig@hum.ku.dk

\begin{abstract}
This article questions common and present conceptions of pre-modern surveillance. A central observation is that sociological and historical readings of surveillance as a historical phenomenon focus on either continuities or discontinuities between pre-modern and modern states and their implementation of surveillance as governmental strategies. This article wishes to avoid such a discussion by focusing on concrete historical cases of surveillance in pre-modern Denmark. In this respect the article is inspired by the genealogical method of Michel Foucault, though it does not claim to be a fully developed genealogy. The article concludes that notions of pervasiveness and scope have to be viewed in proportion to concrete historical contexts.
\end{abstract}

\section{Introduction}

In the spring of 2014 I was sitting in the reading room at the National Archive in Copenhagen. Behind me was a trolley loaded with cardboard boxes of records from the police in Copenhagen. All around me, in fact, several trolleys furnished the reading room and supplied historians, genealogists and others who were scrutinizing all sorts of documents. There, in the reading room at the National Archive, you sense the massive gathering and storing of information about Danish citizens. In my cardboard boxes and ledgers from the police I found registrations of and reports on suspicious and criminal behavior, interrogations of criminals, verdicts from the police court, correspondence between different authorities and much, much more information about the lives of city-dwellers in Copenhagen between 1800 and 1815. My impression was that of a rather fine-meshed net that gave the authorities, primarily the police, good opportunities for distributing information, for gathering information and also for finding people and (possible) criminals and ordinary, decent-behaving citizens in the city of Copenhagen. A surveillance society, I thought.

The period at the beginning of the $19^{\text {th }}$ century is interesting when discussing surveillance and control. On the surface, many similarities between "then and now" can be identified. The Napoleonic wars provided a permanent threat against Denmark that can be compared with the perceived permanent threat that was aroused by the 9/11 attack in 2001 against the Western world in general and by the Muhammad Cartoon Crisis at the turn of 2005-2006 against Denmark specifically. More recently, the attack in Copenhagen on February 14-15, 2015 has underlined the strains of uncertainty and permanent threat. The Napoleonic wars provided external enemies (Great Britain), and the shockwaves triggered by the French Revolution and Napoleon's movements in Europe provoked a rising fear of an internal enemy in the shape of liberal proponents of a new democratic form of government. During this period, the Danish absolutist government extended control over its subjects: censorship was reinforced in 1799, the control over the media landscape was fortified in 1805 and the police in Copenhagen were reorganized and strengthened in 1800-1803 and 
again in 1815-1817. The bureaucracy of the absolutist state definitely gathered, produced and processed much information about its subjects.

My initial thought was that the absolutist state responded to wartime questions and demands in much the same way as modern-day democratic states. Yet the ease with which I identified this as surveillance and equally defined the similarities between "then and now" puzzled me. Such an identification of similarities implies that surveillance and surveillance strategies are the same regardless of time, space and place. This renders surveillance a quality of being supra historical (Foucault 1984: 86). Michel Foucault criticized, with reference to Nietzsche's genealogy, history for neglecting its own historicity and historians for a blindness towards their own taste and preferences (Foucault 1984: 90-91). History runs the risk of judging the past by the truth of today (Foucault 1984: 97) and of identifying continuities and resemblances whilst explaining away differences and errors.

In this article I present a cursory draft of a genealogy of surveillance in Denmark. The purpose of the article is to unravel and question present constructions of surveillance history in the light of two specific cases from Denmark at the beginning of the $19^{\text {th }}$ century. First I introduce present understandings of surveillance as a historical phenomenon with the aim of elaborating the construction of the contemporary "truth" of the history of surveillance. A common viewpoint amongst sociologists is that surveillance was a new and innovative strategy of the modern nation-state with foundations in the late $18^{\text {th }}$ century and Enlightenment (Higgs 2004: 10). This view identifies a discontinuity to preceding forms of government and typologies of states. Furthermore, such an understanding defines pre-modern surveillance as less pervasive and smaller in scope, implicitly relying on a contemporary construction of surveillance. Scope and pervasiveness, according to my assumption, are central to a modern construction of surveillance that is perceived as being worse (i.e. more extensive) than traditional surveillance. Surveillance must, however, be understood in close relation to technological means, media, actors, culture and societal issues-and thus scope and pervasiveness must be seen as contextualized by these conditions. Historians admit more significance to continuities between pre-modern and modern states when it comes to the use of information collection and surveillance strategies. Higgs questions the close link between information gathering and surveillance and shows how later centralized surveillance strategies had roots in decentralized power networks (Higgs 2004).

Second, I draw on two cases from Denmark in the period 1800-1815, where the late absolutist Danish state was under severe pressure from outside conflicts. In these two cases, I explore understandings and practices of surveillance in the pre-modern context of the absolutist state. By looking at technological means, the media environment and actors, I discuss how a specific historical context produced different strategies of information gathering and control. The first case concerns the reorganization of the police in Copenhagen and how they became enmeshed in surveillance practices beyond the surveillance of concrete criminals. The second case deals with the broader field of how the absolutist state sought to control "unwanted" information. Based on these two cases, I argue firstly that the surveillance strategies rested upon complex genre systems and the mechanisms of bureaucracy, and secondly that the use of surveillance strategies became an important part of the enactment of good governance for the absolutist state at the beginning of the $19^{\text {th }}$ century in Denmark. The underlying assumption is that good governance was a question of the maintenance of the absolutist system of rule.

\section{Surveillance and the information state}

The Snowden affair and the US National Security Agency's (NSA) massive tapping of different European prime ministers' telephone conversations and cooperation with the German intelligence agency are merely the most prominent examples of the surveillance capacity of modern states. They demonstrated the extension of a familiar sphere of wartime surveillance of spies and classic intelligence work to a permanent, allpervasive, all-inclusive surveillance based on people's everyday activities using the internet, cell phones or bank cards (Albrechtslund 2016: 11). Surveillance proved to be closely linked to the all-encompassing 
possibilities of ICT that have extended the field of surveillance and empowered new actors with the possibility of surveillance. Besides an "old-fashioned" surveillance conducted by the (welfare) state, private organizations and capitalistic enterprises are now involved in surveillance activities of ordinary citizens. The pervasiveness, the new actors on the scene and the invisibility of surveillance technology brings people a new awareness of "being under surveillance" that to some extent detaches surveillance from its historical origins. Surveillance in peacetime over ordinary citizens without criminal records seems to be a new phenomenon. Perhaps the most striking lesson from the Snowden affair was the public realization that surveillance is more than a mere wartime phenomenon. It is a basic infrastructure in society and it can neither be avoided nor abolished (Albrechtslund 2016: 24). Albrechtslund emphasizes the need for a critical investigation and discussion of how surveillance affects society (2016: 20). One key discussion is how modern ICTs and big data challenge concepts of crucial importance to society's mode of operating, such as, for example, privacy (Mai 2016: 194). Yet the present use of information technologies can be seen as merely a more efficient exploitation of technological possibilities relying on already existing surveillance practices (Lyon 1994: 40). Historians and sociologists agree that surveillance has a history beyond that of Snowden, NSA, and data-traces of the internet. Surveillance - according to Lyon (2001: 1) - has always existed, literally speaking as somebody has always watched over somebody else either in order to monitor or in order to provide care for the other (Lyon 2001: 3).

Much literature discusses surveillance and the present surveillance society. Within sociology, David Lyon's and Anthony Giddens' contributions are substantial. Lyon centers on the interwoven alliance between technology, bureaucracy and surveillance whereas Giddens' analysis of the rise of the nation-state has pointed to the close ties with surveillance. Though both acknowledge that the history of surveillance goes beyond the modern nation-state, they interpret surveillance as a phenomenon primarily associated with the modern nation-state and thus as something distinctly different from the traditional states and even the absolutist states. The nation-state is - in Giddens' terminology-a power-container and relies on an administrative monopoly over a given territory and upholding control with means of violence (Giddens 1985: 121). A distinctive feature of the modern nation-state is the connection to the industrial capitalism of the $19^{\text {th }}$ century. The nation-state was not born overnight but was a result of complex developments emerging in the late $18^{\text {th }}$ century. The modern nation-state seems, in Giddens' version, to have a close affiliation with its immediate antecedent, the absolutist state. However, Giddens stresses the closer affiliation between the feudal state and the absolutist since the modern nation-state is comprised of the combination of capitalism, industrial production, centralization and surveillance. As such, the modern nation-state represents a discontinuity with its predecessors (Giddens 1985: 5, 84). This sociological explanation of surveillance as a historical phenomenon is questioned by Edward Higgs (2004). From the field of information history, he points to a stronger continuity from pre-modern states to the modern nationstates. The emphasis on the modern centralized nation-state diminishes and reduces the powers and strengths of the decentralized pre-modern state. Scholars from the field of information history highlight informationgathering strategies in the early modern state. Higgs, and with him Toni Weller (2012), bridge the differences in forms of government by introducing the concept of the information state and its reliance on information-gathering activities rather than merely presenting them as surveillance strategies.

\section{Surveillance: Continuity or discontinuity}

As a historical phenomenon, surveillance is tied together with information and communication technologies aimed at bureaucratic procedures (Lyon 2001: 1). With this assumption it is also possible to locate a change in the forms of surveillance and date it to the rise of modernity. A central difference, so the argument goes, is the scale of surveillance and also the degree of its pervasiveness in society. With modernity, surveillance became more than just a strategy for punishing individuals, and as a combination of physical observation and the registration and recording of information about subjects, it became a disciplinary instrument (Foucault 1994: 9-44). Foucault argued that this system of discipline was not restricted to the criminal elements in society. It was extended to a fundamental discipline that permeated the institutions of everyday life (the factory, the school, the hospital). Surveillance became a technology of power. 
Increased surveillance is one of the key characteristics of modernity (Foucault 1994; Giddens 1985: 5). Early modern states did perform surveillance through the accumulation of information and as concrete physical supervision but it was not a substantial part of governing before the modern (nation-) state. Traditional states simply lacked a centralized bureaucracy and the means of violence (Giddens 1985: 3849). From this perspective the link between surveillance and bureaucracy is a central constituent when discussing the differences between pre-modern and modern possibilities and forms of surveillanceparticularly when addressing bureaucracy in a traditional Weberian style. Absolutism was characterized by a patrimonial and personal form of bureaucracy in a distinct contrast to the professional, rational bureaucracy of modernity (Dandeker 1990: 41) - roughly speaking, the bureaucracy of the absolutist state governed on behalf of the king and not on behalf of the people. In the absolutist system of rule, the king ruled by the grace of God, in adherence to the initial version of absolutism, and the king was thus not responsible to anyone but God. Enlightenment modified this basic principle and installed a contract between king and people (Feldbæk 2000: 233, 242). Yet this did not mean that the subjects were supposed to interfere in governing or that control over the administration was a public concern or right. This designates a distinctive difference between the location of surveillance activities in the absolutist and the modern state: that the system ruled over and not on behalf of the population (Dandeker 1990: 43). The ties between bureaucracy and surveillance link surveillance to the coding of information. Yet, if surveillance is constituted by "coded information" and direct, physical supervision, the latter was in early modern states restricted to very few situations and spaces e.g. in the cities (Giddens 1985: 14-15). Pre-modern surveillance thus suffered under different constraints, such as technology, demography and the struggles between a weak central state and stronger local power-holders (Dandeker 1990: 54-55). This opinion seems, however, to measure pre-modern surveillance against later standards and (technological) possibilities, which risks blurring how surveillance was actually practiced and understood. In the transition from l'ancien regime towards modernity and the rise of the modern bureaucratic state, surveillance became an increasingly important strategy (Dandeker 1990: 37). Dandeker and Giddens argue for the late- $18^{\text {th }}$ century as a formation period for surveillance and having strong links to the upcoming central (nation-) state and its affiliation with industrialization. Precisely this is questioned by Edward Higgs.

Higgs seems to argue for a stronger continuity between pre-modern and modern states as vehicles for surveillance or rather for information gathering. The close association identified by Giddens and Dandeker between the modern nation-state and surveillance risks blurring the identification and discussion of early modern conceptions of surveillance and control beyond the modern state. Higgs argues that the concept of an information state challenges this association. The term information state suggests that the relations between bureaucracy and the state's demands for information about the citizens and procedures for the storing of it have been close (Higgs 2004: vii). Toni Weller, one of the central proponents of information history, argues that the information state is no more a modern phenomenon than information itself and situates the information state in a kind of longue durée from earlier than 1500 up to 2000 (Weller 2012: 57). The perspective provided by looking at the information state changes lens and facilitates questions about state demands for information, the control exercised with it and surveillance as a way of producing the wanted information. The pre-modern state, in Higgs' words, should be seen as a "...series of overlapping networks exercising authority at all levels of society... (Higgs 2004: 36). By stressing the role of the premodern state it seems that Higgs also wants to undermine a common conception of pre-modern surveillance as being based in local communal, social relations. Yet surveillance changed character as a strategy of the information state between 1500 and 2000.This period witnessed a transformation from a local, loosely organized and less systematized level to a centralized and national level, leading to a more focused, more formalized and centralized surveillance. In this respect, bureaucratization became a primary technology for the surveillance and control conducted by the information state (Weller 2012: 58). Historians and sociologists alike acknowledge and recognize a transformation between pre-modern and modern states when it comes to the employment of surveillance. For Higgs, however, it is important to scrutinize too what he claims as the sociologists' generalized models and explanations (Higgs 2004: 10-11). Thus, Higgs 
advocates empirical studies that can eventually provide possibilities for a stronger theory building (Higgs 2004: 204).

\section{Information and surveillance}

Surveillance and information gathering are often reckoned as being two sides of the same coin and to go hand-in-hand as either surveillance through information or as information as a more or less unintended byproduct of surveillance. The relationship between information gathering and storing and surveillance is not necessarily that straightforward. Many information-gathering procedures were not conceived of as surveillance strategies in order to control the population or distinct parts of the population. Some surveillance strategies were intended to gather or produce information about people, whereas other strategies merely sought to control the dispersion of information. There is no causal, fixed link between information gathering, distribution, production and surveillance, and information gathering can be conducted for quite other purposes than surveillance (Higgs 2004: 11). The intentions behind information gathering or storing systems could be founded in a rather practical discourse (conscription could serve as an example), and yet the potential of the system could easily be combined with a surveillance perspective (Rule 1974: 9). Even if surveillance is understood very broadly as the gathering of and control with information (about individuals) with the purpose of social control (with deviant individuals), it is still not necessarily surveillance for those who "designed" the system (Rule 1974: 8-12). The question of whether surveillance is the actual intention behind a given information-gathering system is open to scrutiny in so far as such systems should be investigated in their historical context. This discussion highlights the fact that historical investigations, besides addressing the intentions behind information gathering, should include investigations of the storing, processing and use of the collected information.

What, then, are the intentions behind surveillance and the more specific surveillance systems? Or on what grounds has surveillance been legitimized? Foucault argues for a strong connection between surveillance and discipline in order to control deviants and make them well-disciplined, good citizens (Foucault 1994). The aspect of social control (to different extents) is a rather obvious one when addressing the legitimization of surveillance. Yet others point to surveillance as a means of incorporating people and enabling social participation (Lyon 1994: 32) and for securing the welfare of the citizens - in short, surveillance as a state governmental strategy connected to policies of legitimizations on a continuum between warfare and welfare (Weller 2012: 61). The demand for welfare (among the population as well as by the state) necessitated knowledge about the population and, as such, welfare became a frequent justification and legitimation of increased surveillance and control. During a war, the need for knowledge about enemies (internal and external), information control and the processing of vast amounts of information is crucial (Weller 2012: 61; Agar 2003: 201-263). In addition, the perceived threat of war is defined as a fair reason and thus legitimizes its increase. In either case the state introduced surveillance strategies as a means for generating and gathering information about individuals. The explicatory force of the continuum between warfare and welfare should, however, not reduce it to yet another general model for explaining surveillance. But it could serve as a way of identifying possible changes in conceptions of surveillance.

The history of surveillance is not the history of a constant refinement of strategies that the modern nationstate invented and improved by use of modern technology. Different technologies and strategies were applied by, for example, the absolutist state in order to benefit the most from surveillance in relation to specific needs in society. If traditional surveillance presents itself to modern eyes as limited, fixed and static compared to modern surveillance as mobile, searchable and shareable (Marx 2014: xxv; Lyon, Haggerty and Ball 2014: 4) this might be the case. But such a contrast risks simplifying the concrete historical situation of, for example, a pre-modern state. It might have been of greater value to the state to fix the information and make it static. A history of surveillance should not call for attempts to make generalizable explanations of the reasons for applying surveillance but empirically investigate how surveillance was understood and practiced in specific historical contexts. 
In the following I address two cases from Copenhagen: the police as an information system, and how the king and his chancellery sought to control information. The closer analysis focuses on surveillance as a wide-faceted strategy that combined with the way "the state" enacted good governance involving local institutions (Higgs 2004: 195).

\section{Denmark under surveillance, $1800-1815$}

At the beginning of the $19^{\text {th }}$ century, Denmark was - to use a modern term-a multicultural state consisting of the two kingdoms, Denmark and Norway, and the two German duchies, Schleswig and Holstein. In addition were different colonial possessions in the North Atlantic, the West Indies, Africa and India. The government was absolutist: all power was united in the hands of the king. The government was bestowed on the crown prince, Frederik VI (1768-1839) since his father, Christian VII (1749-1808), was mentally ill and considered incapable of ruling until his death in 1808. Frederik VI then ruled as king from 1808 until his own death in 1839. Copenhagen was the capital, though no large city-merely 100,000 inhabitants were listed in the census of 1801 (Pedersen 2014: 29). As the seat of the government, Copenhagen housed all administrative institutions and was also the home of the military and naval forces. The city had its own government, the magistrate. Under its remit was, for example, the commercial life. But much fell outside the remit of the magistrate. The fleet and garrison were governed by military jurisdiction, and though the city from time immemorial had watchmen as a crucial aspect of law and order, the police force was under the jurisdiction of the central administration. The city was pressed in behind the city ramparts. The city gates were the main entrances to the city and manifest control posts for the custom officers, whose primary task was to search the ramshackle wagons of the farmers for contraband. The city borders were firm and visible. Inside this enclosure the city consisted of two major sections: the military installations and the civilian city, entirely secluded from each other by different rules. The civilian part of the city was further divided into parishes, quarters and other minor sectors. It is this - the civilian part of the city-that is the basis for the following discussion of information gathering, control and surveillance. It is crucial to emphasize this because the degree of discipline and surveillance was defined by other rules in the military area.

In the period between 1800 and 1815 Denmark was at war. Napoleon's initially revolutionary army swept through Europe and caused monarchies to fall. Danish foreign policy aimed at benefitting from the thriving trade and to find a balance between the threat from Napoleon and an increasing English skepticism towards Danish neutrality. This resulted in two English attempts at gaining superiority in the Sound and to neutralize the Danish fleet, which was successful in 1807 when the Danish fleet was brought to England. This caused Danish foreign policy to favor France, and Denmark faced defeat in 1815 after having been brought to its knees by a state bankruptcy in 1813 and the loss of Norway in 1814. Pedersen (2014) draws on this unstable political situation as the backdrop of the reorganization of the police forces in Copenhagen in 1801-1803 and again in 1815-1817 with the aim of (re)gaining control with the city.

\section{Making the invisible visible: Detecting deviances in the city}

The police work generated many different genres, and the unravelling of the genres and genre systems used by the police and other authorities pointed to the existence of different information channels and networks for the dissemination and gathering of information (Skouvig 2015). These channels provided the authorities with access to a multitude of different strategies and technologies for keeping an eye on the population in Copenhagen at a turbulent time in Danish history. Even though Copenhagen was a rather small city, gossip and rumors prospered in the streets and abusive language, slander and libel were among the most frequent entries in the main journal of the police. Drunkards, tramps and other social outcasts made the streets seem insecure for the bourgeois. When you deal with police archives you have to keep in mind the lopsidedness of the records. What you see is the unpolished - and criminal - side of society, including the rawness of the streets with abusive language, drunks, prostitutes and criminals (of different kinds). What the files also revealed was that the police commissioner had direct contact with, for example, tax collectors and, naturally, the watchmen of the city. This net of contacts was used in 1807 to prepare the city for war (Skouvig 2015) 
but could also be activated for finding specific individuals. It definitely exposed the fact that the police possessed a rather close knowledge about the city and its inhabitants that could be used either for taking care of the population or for the more specific interest of the absolutist system of rule.

Gaining control over the city implied an extension of the existing divisions of urban space, and bureaucratic improvements were implemented in the police force. In 1816 the police administration created a new position of police inspector. This inspector was assigned to a police district, which was a new administrative division of the city across the existing and traditional quarters and parishes. The police inspectors were instructed to maintain law and order and ideally to watch over law-abiding citizens. In the detailed instructions it was stated that the new police inspectors should acquire knowledge about all residents in their districts - particularly about potential troublemakers (Pedersen 2014: 127). The reorganization of the police in Copenhagen at the beginning of the $19^{\text {th }}$ century was intended to protect the king, the city and its inhabitants. First of all, the intention was to handle committed criminal offences. Secondly, the period witnessed an ascending interest in pre-emptive measures against possible deviances. According to Pedersen (2014: 126-131) the police reorganization established a direct connection between the partitioning of the city and the need for surveillance. The means of surveillance was, as mentioned above, a new bureaucratic partitioning of the city combined with a direct, visible surveillance by the presence of uniformed police. At the same time, different forms of bureaucratic registration were introduced and intensified (Pedersen 2014: 28).

Physical means and bureaucratic procedures were introduced for an increased surveillance of the inhabitants in Copenhagen in general, and the potential criminal elements in particular. A core element in the reorganization was the establishment of a simple classification of the population: the strangers, the deviants, the law-abiding citizens and those with a potential for criminal deviance (Pedersen 2014). The latter group thus consisted of actually law-abiding citizens with no disputes with the police - apart from being categorized according to an enhanced interest from the side of the authorities. Members of this group were servants, journeymen and increasingly liberals in opposition to the absolutist government. The former group, the strangers, included everybody who did not come from the capital or the province of Zealand. All strangers had to bring with them a passport when traveling from or to Copenhagen. In 1801 the task of issuing these passports was transferred from the magistrate to the police, and it was further intensified during the period with reference to the state of war in Europe (Pedersen 2014: 83, 157). A special office was established whereby all visitors had to report on their arrival, as did those strangers traveling from Copenhagen. In this way the police passport office turned into a crucial institution for information management and a site for accumulated information about strangers. Besides this, the tasks at the office required a rather good knowledge of the city and the whereabouts of the strangers. The staff at the police passport office were later involved in concrete surveillance of criminal gangs as well as oppositional groupings (Pedersen 2014: 226-231).

From 1812 onwards, the parish registers nationwide provided surveys about newcomers to a parish and the names of those who left. However, Copenhagen was exempted from this rule. As a substitute for the parish registers, the new police inspectors were given the task of conducting house registrations every six months in order to keep a census of the city and to register the residences of servants and day-laborers. This task demanded procedures for the storage and processing of the collected information. These two forms of registration illustrate how surveillance strategies of the early modern information state anticipated later information-gathering strategies as a national register of the population, yet the reasons for collecting the information were different. Why was it necessary to count the population? And what pieces of information were to be read from these censuses? The reports indicate that it was particularly important to gain an estimate of the whereabouts of the particular problematic groups. Another purpose could be to procure an indisputable identification of potential criminals in court (Pedersen 2014: 125). The ambiguities of the intentions behind the house registrations incorporate the general discussions of the double-sided face of surveillance. The house registrations can be interpreted as either controlling the population or as securing 
civil rights. In the latter case the registrations should guarantee that nobody was convicted without a proper identification.

Information about the population accumulated in piles. In particular, the local police inspectors' offices bore evidence of the massive abundance of information that should be stored. Thus, surveillance was not only present in the streets - it took on material shapes such as the passport, parish registers, printed forms for house registrations, completed forms and later conduct books for servants and journeymen (introduced in the 1830s). Passports and conduct books took this bureaucratic surveillance beyond the walls of the city and involved the population directly, for example in assessing the character and conduct of servants. The issue of materiality was particularly present in the passports: If they were printed on thick paper they were easy to forge; if they were printed on thinner paper they could barely hold the seal and easily cracked with use (Pedersen 2014: 86).

The identification of persons was a rather important element in the absolutist administration of justice. The courts of justice could not sentence a person without sufficient identification of his/her identity. So when a woman named Marie Cathrine Jacobsdatter was brought before the Police Court on September 25, 1807 for selling broadside sheets it was particularly important to question her on her age, her place of birth, the names of her parents and her deceased husband. Later her landlord appeared and confirmed that she rented a room at his place (DC-013 33-11; case 874/4036). This seemed to be a routine practice in the interrogation of prisoners in Copenhagen. The police systems handled information about criminals: in ledgers the names of felons, their crimes and their path through the legal system were registered. Ballad-mongers were, after a resolution in 1805 (see later), turned into criminals. Laws meant criminal offenders and ballad-mongers were arrested, brought in to the police station, interrogated, put into custody and later brought before a judge in the Police Court. All these steps generated information that was meticulously recorded: in the main register of the police; in the records of the Police Court; and finally in the dossiers that were generated as part of the investigation of some of the cases. These dossiers frequently included statements from landlords, husbands or others who knew the arrestee (DC-013: (942)-4309).

With the ledgers the police were able to identify repeated offences committed by the same individual. The police ledgers were established to furnish the system with information in order to decide on the correct convictions in court. Establishing a secure identity relied on information about place of birth, and visual identification through the use of witnesses. People who traveled across borders and were unknown to the citizens in Copenhagen challenged the prevailing possibilities for identification and were, without identification, simply strangers.

The surveillance strategies in Copenhagen at the beginning of the $19^{\text {th }}$ century were double-faced: securing the interests of the governing system, surveillance also aimed at securing the safety of the law-abiding citizen. They seemed to fight the invisibility of the individuals and make them visible. The combination of physical, concrete surveillance with the bureaucratic gathering of information about the population meant that the individual could no longer hide in the crowd. They were rendered visible through documentation and registration. In this way the strategies of surveillance were intended to prevent the disappearance of bodies (Lyon 2001: 15-27).

\section{Slipping through the fingers: Information as the enemy of state}

The information culture of Danish absolutism revolved around information as something to be controlled. This was evident in other pre-modern states. A key area for early modern states was information control as an aspect of governing (de Vivo 2007: 4). Information was necessary for the state as an instrument for decision-making (cf. Rule 1974) while at the same time information could turn into a major problem for the government. The city worked as a sounding board for information and consisted of communication channels and centers (marketplaces, printing offices, bookstores, pharmacies and barber shops) through which information circulated from the political elite to the wider population (de Vivo 2007: 86-112). During the 
Napoleonic wars, king and government conceived of it as necessary to control the information that swept through the streets, the confectionaries, coffee-shops and public houses. And though information circulated out of control it remained important to preserve the boundaries between the political elite and the broader population (which allegedly had no interest in policy). In the following, I discuss what kind of information the absolutist government wished to control in particular, and what measures it implemented in order to conduct information control.

The fight against rumors was a substantial area for the absolutist control over communication. The crown prince feared revolution. This fear found a rather concrete manifestation in the tightening of the liberty of the press in 1799 and (later) the suppression of different liberal groups in the country (Engberg 2009: 460465; Pedersen 2014: 132-135). The content of newspapers and other printed material was easily controlled and watched over. All publications had to be previewed and carry the name of the author and of the printer, and the newspapers contained only harmless news; not, for example, state affairs or domestic policy (Lehrmann 2001: 78-89). The newspapers presented the international news without comment and left it to the reasoning of the citizens themselves. Frederik VI did not hesitate to forbid the newspapers writing about certain international news, such as the flagrant defeat of Napoleon in Russia. According to Engberg (2009: 372) the Russian envoy in Copenhagen found this so outrageous that he set up a reading room with access to foreign newspapers. Unfortunately, Engberg does not refer to whether this opportunity was seized by the citizens in Copenhagen, but the example is interesting as a case of how surveillance and control led to the bypassing and challenging of power.

News came in printed form as well as handwritten (i.e. not just as letters but also as handwritten pamphlets or ballads). More than anything else it was oral. Ballad-mongers were a vibrant and rather noisy element in the everyday life of Copenhagen, with their gory stories of the latest catastrophes. They were considered such a nuisance to the decent townsmen that the royal chancellery in 1805 issued a resolution about rumors and their dissemination (Schou 1808: 379f). The resolution referred to the decree of 1799. Though this decree did not officially re-impose censorship, it worked as such in practice because it simply defined what could be printed (Engberg 2009: 282). The 1805 resolution stressed that rumors were not to be disseminated in printing, writing or song. The media environment in Copenhagen was rather complex to control and there was a critical public. It was not just a cultured public, as the ideal portrayed in Habermas' works on the public sphere, but a public of the streets (Habermas 1990: 86-122; Darnton 2010: 139). This public of the streets was a key area of interest to absolutist governments such as, for example, the French. In prerevolutionary Paris, the government sought to control the public through a fine-meshed net of informants (Darnton 2010: 71). The revolutionary government and later Napoleon continued this strategy under the auspices of the police commissioner, Fouché - a network that the Danish crown prince admired as his own distrust of citizens' loyalty grew (Engberg 2009: 367). Engberg (2009: 373, 392) states that the critical situation in Denmark after the bombardment of Copenhagen in 1807, an approaching state bankruptcy (1813) and not least the loss of Norway in 1814, meant that Frederik VI was deeply unpopular with the population. In such an atmosphere of disconcertment and secrets, rumors thrived and were ascribed importance to such a degree that the government found it necessary to prohibit them. But rumors knew no limits and traveled - in letters, as messages, in newspapers, in broadsheets and orally.

In 1812, in light of a climate of insecurity fed by the many years of war, the king addressed his subjects in an open letter. Frederik VI worried about the rumors and their influence on his subjects. He urged them not to pass on untrue intelligence and not to believe in strolling rumor-mongers (Royal Open Letter 1812). Fearing what the crowd would do on the basis of rumors, the King turned to people of a certain culture, addressing their self-image of reflectiveness in order to scrutinize all information received. Invoking the patrimonial relationship between king and subject, the king stressed that he could not imagine that his people would act malevolently by dispersing information. He warned them, though, that they exposed themselves as bush telegraphs (Royal Open Letter 1812). Merchants were connected to international news, both trustworthy and unreliable, through their business correspondence and networks and a focal point was to 
instruct the merchants how to handle the information. The strategy of the government was twofold: on the one hand the government wished to stop the flow of uncontrolled information from abroad as well as locally produced information. On the other hand, the government was extremely interested in learning of reliable intelligence that could be important to the government. If the information was reliable it was the duty of a good citizen to inform the royal government (Royal Open Letter 1812). Government control over information opened a possibility for the good citizen to define him/herself by understanding how control over information worked.

The surveillance of mail and letters was intensified in the period 1800-1815 pivoting around the postmaster who handed out the mail at the local post office. On public lists everyone could see if there was mail. Blank spaces on these lists indicated that letters had been brought in for censuring (Pedersen 2007: 200). The postmasters were actively involved in the surveillance of correspondence by mail. Post decrees had for a long period prohibited the postmasters from opening and reading letters unless it was by governmental order. Most recently this was emphasized in a decree in 1784 (Pedersen 2008: 254). The censorship of letters fluctuated in the period 1800-1815 and had varying arguments. Pedersen (2007: 196-202) argues that the absolutist government maneuvered between an open, disciplining censorship and a secret, intelligencefocused censorship. In the former, surveillance and censorship were visible through the blank spaces on the mail lists. The secret, spy-related opening of letters had the primary target of securing information revealing neither sources nor enterprise. The open, disciplining censorship of letters should be seen together with the wish to control rumors and was related to a wish of the absolutist government to control public opinion in general (Pedersen 2007: 188). Letters were conceived of as private-save when the king had an interest in them. The absolutist state had, in a situation characterized by unrest, increasingly taken an interest in the private life of the individual citizen and issues that belonged to the private sphere in the Habermasian sense (Habermas 1990). Even though, roughly speaking, the border between the private and the public for the city-dwellers was the threshold between property and the street, the debates about the 1799 decree showed an understanding of the differences between the public (government affairs) and the private realm (the life of the citizens). It is, however, a crucial characteristic of absolutism that irrespective of having been written in a private letter, critique against king and government was considered a crime. The open disciplining censorship of letters was controversial as it broke the alliance of trust between the postal service and its clients by violating the border between public and private (Pedersen 2008: 181).

The absolute king worried about rumors that had the potential of igniting whatever minor discontent existed among the mob. The resolution of 1805 and the Royal Open Letter from 1812 supported the image of the worried paternal monarch who wished to secure the privacy and safety of his subjects by fighting rumors. But rumors were evasive: some were reliable and contained trustworthy information needed by the government in order to fight the enemies. Information control relied on restrictions against the liberty of the press, the distribution of news and the capture of private mail. This supports the notion of a state of war-a war that took place on two fronts for the Danish king. He fought against the British as the external enemy, but internally, the fear against oppositional groups in Denmark increased (Engberg 2009: 457-462). By imposing censorship on publicly accessible information and by controlling private correspondence, the government installed disciplining measures of a panoptic nature in the population. The question here is thus whether this kind of information control is related to a modern conception of surveillance or whether this reflected the understanding of the father who supervised his children by monitoring their games.

\section{Pre-modern surveillance}

A net of surveillance was tightened around the individual at the turn of the $19^{\text {th }}$ century. It consisted of visible and physical elements and at the same time it had an invisible, bureaucratic counterpart in records and documentation by, for example, the police inspectors. In Copenhagen the old control posts at the city gates were reminiscent of the medieval city and were reminders of an intense surveillance of the population. But it was no longer a possibility to simply lock up the city at night in order to prevent disorder. The police upgraded, and censorship in the printed press, just as in private correspondence, tightened. There was an 
impression amongst people that letters were opened with the aim of controlling public opinion (Pedersen 2007: 200). The incidents of the French revolution had sharpened the sensitivity against critique from the side of enlightened bourgeoisie and the fear of an uprising amongst the lower part of the population. Pedersen (2014) argues that the reorganization of the police should prevent a merger between the intellectual critique and the disconcertment among the mob. Information control shared the aim of preventing riots. Rumors were dangerous because they could lead to unpremeditated actions from the side of the mob. Against the backdrop of the unstable political situation with revolution and war, invisible surveillance strategies of bureaucratization and information control were applied by the late absolutist government. It is to be considered whether it was the security of society in general or rather the security of the absolutist government and the king that was central to the surveillance strategies at the beginning of the $19^{\text {th }}$ century. The strict interrogation of felons by the police indicates that surveillance to some extent was a consequence of bureaucracy itself.

At the beginning of the $19^{\text {th }}$ century the Danish system of rule was a patrimonial, personal system, and though surveillance was conducted by specialized officials there was no public control. The absolutist government had a strong interest in tight control over the streams of information. The intention was to reproduce a system that ruled over the population, not on behalf of it. Surveillance of and control over the population were used strategically and intensified during the period. The need for documentation became the invisible consequence of surveillance through which the population was systematized and classified. Information control focused on surveillance of information itself. Surveillance was an aspect of government and relied on an expanding state bureaucracy, combining existing systems with new needs for finding, producing, controlling and storing information. Information control was a way for the government to define its own borders regarding the population.

\section{Concluding remarks}

From a contemporary perspective, pre-modern surveillance exhibits similarities with, and differences from, surveillance strategies in our late-modern world. The state emerged as a central actor exploring means at hand. Bureaucratization was a substantial part of the emergence and formation of the information state for handling complex accumulation of information. As Foucault argued, bureaucratization and information collection were not merely a question of state administration led by civil servants. It also took place in the barracks, in the factories and in the schools (Foucault 1994: 276). Bureaucratization expressed a wish for a firmer hold on state and society (Feldbæk 1982: 84), and the enhanced emphasis on state administration resulted in increased knowledge production about the population. The productivity of the country depended on a healthy population, as argued by Foucault (1983). In combination with a fear of the French revolution, the Danish King and central administration were interested in different ways of tightening control over information and the Danish population. Though the application of ledgers and the reorganization of the police force, together with censorship of the press and media in general, seem to be less pervasive and less complex in comparison with present-day information technology, the striking feature of pre-modern surveillance was how it involved everyday practices of those who watched and those who were watched over. Surveillance was just as varied, multi-faceted and complex as today.

Historical investigations into surveillance should not search for its origin but rather try to trace some of the branches of modern surveillance. This is, as in this article, very easily done by looking at the state. Having focused the lens on the strategies of the late absolutist state I have wished to challenge present conceptions of pre-modern surveillance as being less pervasive and of lesser scope. On the other hand, I do not wish to claim that pre-modern surveillance was of the same scope and degree as modern ICT-based surveillance. If we want to understand surveillance in our present society we need to scrutinize general explanations and conceptions of surveillance in order to explore differences and varieties that are not only spatial but also temporal. 


\section{Acknowledgments}

I wish to thank the two anonymous reviewers for their insightful, helpful and productive comments. This article is a rewritten and extended version of an original Danish article: Skouvig, L. (2014). Efter indhentet efterretning: Et historisk rids af overvågning $\mathrm{i}$ enevældens København. Nordisk Tidsskrift for Informationsvidenskab og Kulturformidling 3(2/3): 7-17.

\section{References}

Agar, Jon. 2003. The Government Machine. A Revolutionary History of the Computer. Cambridge, MA: The MIT Press.

Albrechtslund, Anders. 2016. Overvågning. Tankepauser 39. Aarhus: Aarhus Universitetsforlag.

Skouvig, Laura. 2015. Genres of War: Informing a City. In Genre theory in Information studies, Studies in Information, Vol. 11, edited by Jack Andersen, 135-156. Bingley, UK: Emerald Group Publishing Limited.

Dandeker, Christopher. 1990. Surveillance, Power and Modernity. Bureaucracy and Discipline from 1700 to the Present Day. Cambridge: Polity Press.

Darnton, Robert. 2010. Poetry and the Police. Communication Networks in Eighteenth-century Paris. Cambridge, MA: The Belknap Press of Harvard University.

de Vivo, Filippo. 2007. Information and Communication in Venice. Rethinking Early Modern Politics. Oxford: Oxford University Press.

Engberg, Jens. 2009. Den standhaftige tinsoldat. En biografi om Frederik VI. Copenhagen: Politiken.

Feldbæk, Ole. 1982. “Tiden 1730-1814.” In Danmarks Historie, Vol. 4, edited by Aksel E. Christensen, Hans P. Clausen, Sven Ellehøj and Søren Mørch. Copenhagen: Gyldendal.

Feldbæk, Ole. 2000. "Vækst og reformer-dansk forvaltning 1720-1814.” In Dansk Forvaltningshistorie, Vol. 1, edited by Leon Jespersen, Erling Ladewig Petersen and Ditlev Tamm. Copenhagen: Jurist- og økonomforbundets forlag.

Foucault, Michel. 1983. "Der Wille zum Wissen.” Vol 1 of Sexualität und Wahrheit. Frankfurt am Main: Suhrkamp Taschenbuch Wissenschaft.

Foucault, Michel. 1984. Nietzsche, Genealogy, History. In The Foucault Reader, edited by Paul Rabinow. New York: Pantheon Books: 76-101.

Foucault, Michel. 1994. Überwachen und Strafen. Die Geburt des Gefängnisses. Frankfurt am Main: Suhrkamp Verlag.

Giddens, Anthony. 1985. "The Nation State and Violence." Vol. 2 of A Contemporary Critique of Historical Materialism. Cambridge: Polity Press.

Habermas, Jürgen. 1990. Strukturwandel der Öffentlichkeit. Untersuchungen zu einer kategorie der bürgerlichen Gesellschaft. Frankfurt am Main: Suhrkamp Taschenbuch.

Higgs, Edward. 2004. The Information State in England. The Central Collection of Information on Citizens since 1500. Basingstoke: Palgrave Macmillan.

Lehrmann, Ulrik. 2001. “Avisernes offentlige mening.” In Mediernes forhistorie og 1840-1880. Dansk Mediehistorie, edited by Klaus Bruhn Jensen, 69-91. Vol. 1. Copenhagen: Samfundslitteratur.

Lyon, David. 1994. The Electronic Eye. The Rise of Surveillance Society. Cambridge: Polity Press.

Lyon, David. 2001. Surveillance Society. Monitoring Everyday Life. Buckingham and Philadelphia: Open University Press.

Lyon, David, Kevin D. Haggerty, and Kirstie S. Ball. 2014. "Introducing surveillance studies." In Routledge Handbook of Surveillance Studies, edited by Kirstie S. Ball, Kevin D. Haggerty and David Lyon 1-13. New York: Routledge.

Mai, Jens-Erik. 2016. "Big data privacy: the datafication of personal information." The Information Society 32: 192-199.

Marx, Gary T. 2014. "Preface: 'Your papers please': personal and professional encounters with surveillance." In Routledge Handbook of Surveillance Studies, edited by Kirstie S. Ball, Kevin D. Haggerty and David Lyon, xx-xxxi. New York: Routledge.

Pedersen, Sune C. 2007. "Prinsens grå kabinet. Brevcensur og postspionage i efteråret 1807.” In København 1807. Belejring og bombardement, edited by Peter Henningsen, 182-205. Copenhagen: Jyllands-Postens Forlag.

Pedersen, Sune. C. 2008. "Brudte Segl. Spionage og censur i enevældens Danmark." Vol. 7 of Skrifter fra Post \& Tele Museum. Copenhagen: Post \& Tele Museum.

Pedersen, Karl P. 2014. Kontrol over København. Odense: Syddansk Universitetsforlag.

Royal Open Letter about rumors, 26. July 1812.

Rule, J. B. 1974. Private Lives and Public Surveillance. New York: Schocken Books.

Schou, Jacob. H. 1808. Chronologisk Register over de Kongelige Forordninger og Aabne Breve, samt andre trykte Anordninger som fra Aar 1670 af ere udkomne, tilligemed eet nøigtigt Udtog af de endnu gieldende, for saa vidt samme i Almindelighed angaae Undersaatterne i Danmark og Norge, forsynet med et alfabetisk Register. 14. Copenhagen: Hofbogtrykker Christensen.

Weller, Toni. 2012. "The Information State. An historical perspective on surveillance." In Routledge Handbook on Surveillance, edited by Kirstie S. Ball, Kevin D. Haggerty and David Lyon, 57-63. New York: Routledge.

\section{Material from the Danish State Archives (DC-013).}

I refer to material from the Police Court in Copenhagen "DC-013, 33-11. $4^{\text {th }}$ Protocol, 1801-1845, Interrogations 1807-1810." This originates from the archives of the police department. 